\title{
USE OF SELF-ORGANIZING MAPS IN THE IDENTIFICATION OF DIFFERENT GROUPS OF RECLAMATION SITES IN THE AMAZON FOREST-BRAZIL
}

\author{
A. I. RIBEIRO ${ }^{1}$, R. M. LONGO ${ }^{2}$, F. H. FENGLER ${ }^{1}$, G. DE A. MEDEIROS ${ }^{1}$, A. BRESSANE ${ }^{1}$, \\ D E. CROWLEY ${ }^{3}$, W. J. DE MELO ${ }^{1}$ \\ ${ }^{1}$ University State of São Paulo, Brazil \\ ${ }^{2}$ Pontifical Catholic Unive rsity of Campinas, Brazil \\ ${ }^{3}$ University California Riverside, USA
}

\begin{abstract}
Brazil has the third largest reserve of contained tin, around $12.3 \%$ of the amount produced in world, being a large part of these reserves located in the Amazon region. As a result of this mineral wealth, the Amazonian ecosystem has been suffering a rapid process of environmental degradation since the sixties. In this sense, given the mining adverse consequences to the environment, Brazilian Constitution obligate the land reclamation of degraded areas by mining and it has been performed by the majority of the mining companies. However, given the environment complexity and its relationship with the biological diversity, there is a great necessity of better understanding in assessment of evolution of these degraded areas in recovery. Thus, the present work had as objective identifying different groups of degraded areas in reclamation process by means of soil texture, biochemistry and vegetation indicators. The data was analyzed through Artificial Neural Networks (ANN) Self Organizing Maps (SOMs). The results showed four different groups and it was identified a relationship between the different textures soils as a result to the recovery method applied.
\end{abstract}

Keywords: Amazon Forest, Tin mine, Recovery, Soil

\section{INTRODUCTION}

Brazil has the third largest contained tin reserves, ie about $12.3 \%$ of the world total, and most all of these reserves are located in the Amazon region [1]. As a result of this mineral wealth, the Amazon ecosystem is undergoing an accelerated process of environmental degradation since the 60ths. In this insertion, it is observed that the land reclamation of mined areas is part of the Brazilian Federal Constitution and has been held by most companies in Brazil.

However, given the complexity of the environment and its relation to biological diversity, there is a great need for evolutionary understanding of the areas in reclamation. In this scope, the extraction of cassiterite in open mine presents itself as one of the most common techniques used in the mining region of the Brazilian Amazonia [2]

This mining technique employs a process almost entirely mechanical, using various earthworks and transport equipment, whose own traffic significantly alter soil characteristics where the mineral is being exploited. These changes, or environmental damages, reach the maximum during the mining process, where the density difference process, which separates the mineral to several tons of waste containment basins, occurs. In sequence, even with 
plowing already performed, other operations that follow the removal of the ore also cause degradation.

In this sense, the present study aimed to understand the different groups formed by the analysis of land reclamation indicators, using the Artificial Neural Networks Self-Organizing Maps in the clustering process. Thus, we sought to understand the similarities between different substrates in which the in reclamation areas lies. The Self-Organizing Maps were made by the following indicators: Particle size of soils substrates, soil organic matter, water retention, microbial biomass, dehydrogenase, species richness per parcels and number of arboreal individuals per hectare

The data were analyzed by the Kohonem Self-Organizing Maps, which consider the data visualization technique developed by Professor Teuvo Kohonen, in early 80ths. This technique is capable of mapping multidimensional data to subspaces to lower dimensions, where geometric relationships between points show by its likeness. The reduction of dimensionality that SOMs offer allows the users to view and to interpret patterns that would be indecipherable or intelligible to a complex condition of multidimensionality in the original data.

\section{MATERIALS AND METHODS}

\subsection{Characterization of the study area}

The National Forest of Jamari (FLONA Jamari) Figure 01 covers an area of approximately 225.00 hectares, where $90 \%$ are covered by Open Rainforest, where significant commercial wood value is founded and also rich in minerals reserves.

The climate classification according to Köppen is Aw, indicating hot and humid climate season, with short dry season, and average temperatures of $22^{\circ} \mathrm{C}$. The annual rainfall in placed between 1750 to $2750 \mathrm{~mm}$, and the relief unit that dominates the landscape is the Western Amazon's Downgraded Plateau with altimetry ranging between 100 and 200 meters.

The National Forest of Jamari is included in the category of sustainable use unit and its vegetation are composed by open rain forest with small patches of tropical rainforest. The main soils in the study area are: oxisol and ultisols and hydromorphic soils [2].

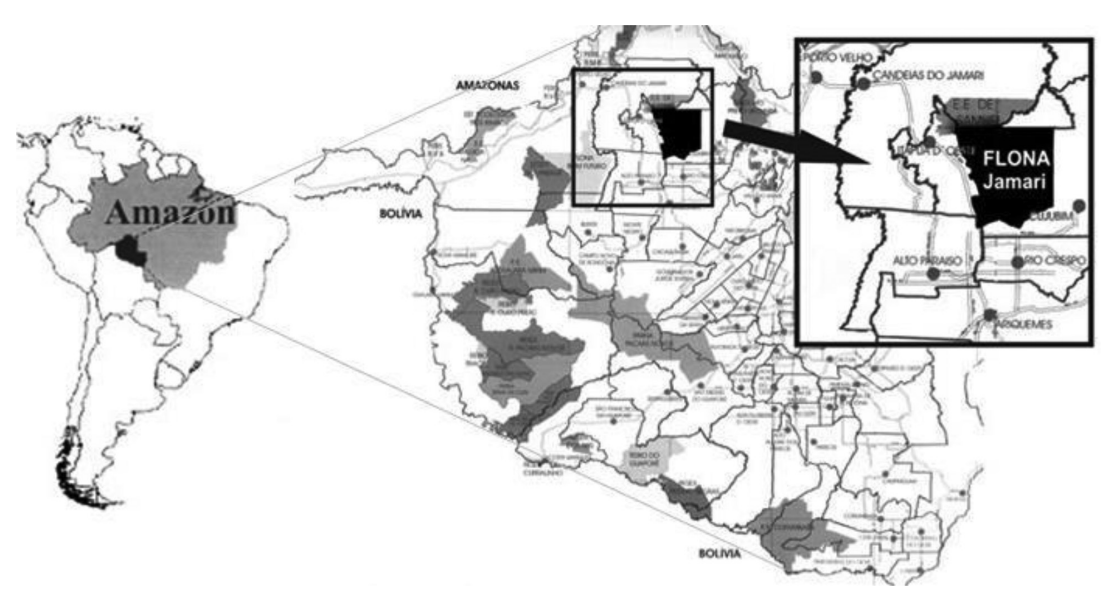

Figure 1: Jamari National Forest Location. (Font: adaptation [9]) 


\subsection{Soil substrates}

The self-organizing maps analysis was applied in four different substrates, however for the development work we used only the pit mine and dry overnburden substrates. This choice was defined in order to understand the scope of Self Organizing Maps, because these tow substrates have the most different grain sizes.

\subsection{Land reclamation indicators}

The self-organization maps were generated using indicators variables that were sensible to soil grain size differences between the degraded substrates:

- Variable water retention capacity (WRC): To determine the WRC was used the method of Richards pressure chamber, described by EMBRAPA [3]

- The carbon in the microbial biomass (CMB) was determined according to the methodology described by [5]

- The determination of dehydrogenase activity was made by the method described in [5].

- Soil organic matter (OM) was determined according to the methodology presented by [2]

- Species richness per parcels (parcels richness) was determined in each experimental area within the parcel set in the experiment.

- The number of arboreal individual per hectare (individuals tree/ha ) was determined by counting individuals with diameter at breast height $(\mathrm{DBH})$ greater than $10 \mathrm{~cm}$ in the parcel and later estimate per hectare.

\subsection{Artificial neural network analyses}

ANN analyses were conducted using the software Synapse (Peltarion Corporation, Sweden) following the protocols provided by the modeling program. The data were first entered into EXCEL files where they were inspected, randomized, and then saved as text files for import into Synapse. Kohonen SOM were generated from the full data set, including both the independent and dependent variables [6].

However, in the development of this work we considered the potential of display groups formed in the self-organizing maps in an output network composed by a mesh of virtual units or artificial neuron of two dimensional 15x15 neurons. The modeling process with Kohonen Self Organizing Maps was based on the methodology presented by [7].

The dimensionless set was projected in a nonlinear way in to a rectangular grid and on a hexagonal grid with $\mathrm{S}$ hexagons, called Kohonen map (Figure 03a).

Each hexagon shown in Figure 1b is an artificial neuron called Virtual Unit (Virtual Units or - VU). These units represented by (Vuk) $1 \leq \mathrm{k} \leq \mathrm{S}$ correspond to virtual places that house the data represented by ( $\mathrm{sik}) 1 \leq \mathrm{i} \leq \mathrm{n}, 1 \leq \mathrm{k} \leq \mathrm{S}$. At the end of the output layer calculation routine, which consists of the set of Virtual Drives, will present the Sampling Units allocated in their respective positions, constituting the SOM (Kohonen map).

The algorithm of Self Organizing Maps Kohonen search position the Sampling units similar in the same regions of the Virtual Drives, preserving the neighborhood between VUs. The positioning of the Sampling Units occurs by simulating the functioning of the human brain process by Artificial Neural Network (ANN), for interactive settings.

The method lacks a learning stage, where the neural network is trained to perform the allocation of sampling units in the correct locations of Virtual Drives. For learning only, the 


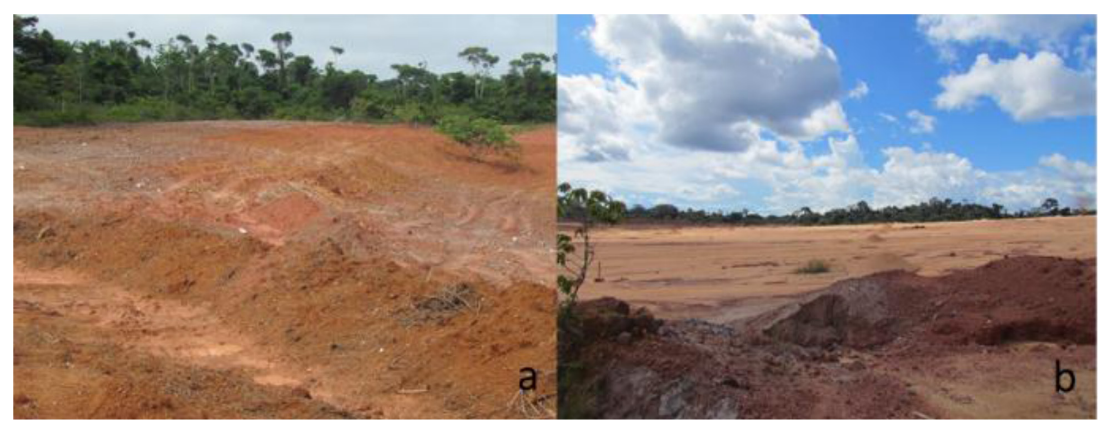

Figure 2: Substrate pit mine letter a and substrate overnburden letters $\mathbf{b}$

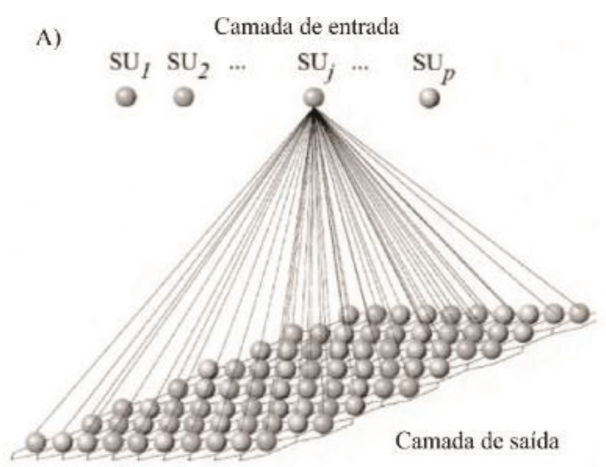

B)

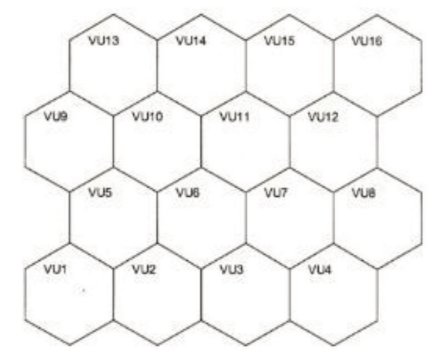

Figure 3: (A) Map Self Organizing of two dimensions, each sphere symbolizes the neurons of the input layer; (B) Auto Organized Map (Kohonen map) formed by a rectangular grid with the virtual drive Vuk or artificial neuron in each hexagon. Fonte: Adapted [7].

input units will be used and no output will be displayed by the system and an unsupervised learning.

\subsection{Data analysis}

For verification of the interactions observed in the self-organizing map we used the correlation matrix of variables, measured by the Pearson coefficient.

\section{RESULTS AND DISCUSSION}

The U-matrix (Figure 04) represents a unified distance matrix, and through it we can visualize the distance between the neighborhood of the map units, that is, it becomes possible to observe all the Clusters on the map. This image of the U-matrix can be used to view the data in a high - dimensional space using a $2 \mathrm{D}$ image. It is observed that it was possible after network training differentiate four clusters.

In Figure 05 we observe that the self-organizing maps for different substrates, where it was applied the revegetation techniques. The group of neurons shown that the maps of different 


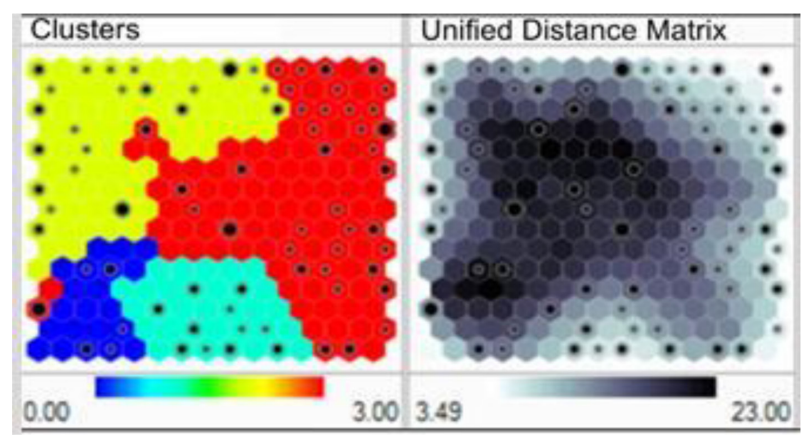

Figure 4: Clustering in colors and U- matrix (unified distance matrix) in gray.

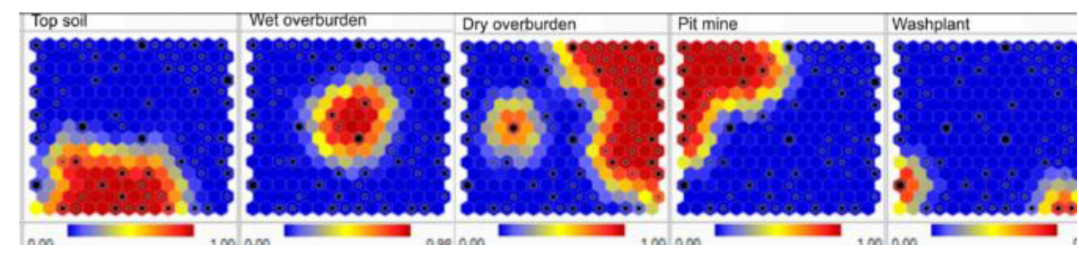

Figure 5: Maps SOM self-organizing for different substrates in recovery.

substrates do not have spatial regions of similarity. Thus, the choice of these substrates as areas with different behavior for recovery, showed compatible with the results. Thus, the pit mine substrates and dry waste(overburden) are discussed in relation to the recovery indicator variables.

In Figure 06 the self-organizing maps relating to particle size classification and particle size are presented. The construction of these maps was carried out to identify the display range of groups of neurons for different substrates. It is observed that the spatial similarity clustering of different textures are compatible with the levels of particulate clay, silt and sand. It is clearer the visualization of the similarity of the cluster maps of neurons for clay texture classification and sand. The average texture didn't present a well-defined similarity with the granulometric levels.

The maps of indicator variables are shown in Figure 07. It is observed that most of the indicators has a region with the top left neuron groups. This region corresponding to the pit mine substrate which features fine particle sizes such as sand and silt. According to [8] the variables: microbial biomass, organic matter, and dehidrogease have showed good indicators for areas in reclamation. We note that the soil water retention capacity also shows significant in this region. However, regarding species richness indicator variable per parcel and the number of individual tree per hectare, there is a spatial representation of neuronal groups with similar trends. Thus, it can be inferred that the local revegetation by planting seedlings of native species has aided the recovery of disabled tin mines in the Amazon rainforest.

Table 1 shows the correlation matrix between the indicator variables. It is observed that most of the correlation (Pearson coefficient) were low. However, the highest correlations support the similarities neuron clusters in self-organizing maps. Note that the correlation between the number of arboreal individuals has a correlation of 0.62 with the wealth of individuals 


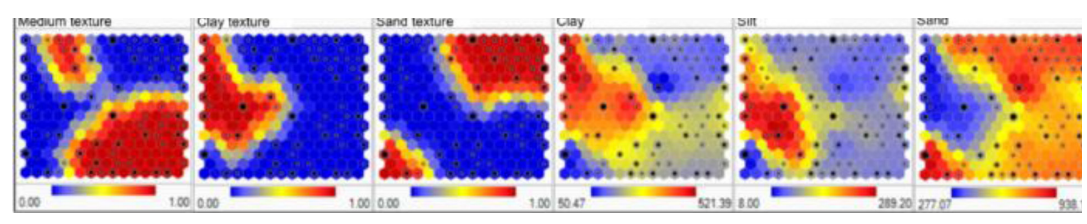

Figure 6: Self-organizing maps SOM for particle size and classification of textures in the substrates in recovery.

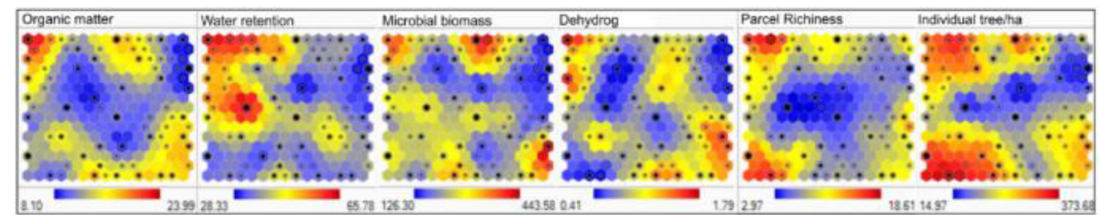

Figure 7: Indicator variables: organic matter, water retention, microbial biomass, dehydrogenase, species richness per parcel, individual tree per hectare

Table 1. Correlation matrix for the studied variables.

\begin{tabular}{lccccccccc}
\hline $\begin{array}{l}\text { Correlation } \\
\text { Matrix }\end{array}$ & Clay & Silt & Sand & WRC & CMB & Desid & OM & P. rich & Arbo indiv \\
\hline Clay & 1 & --- & --- & --- & --- & --- & --- & --- & --- \\
Silt & 0.622 & 1 & --- & --- & --- & --- & --- & --- & --- \\
Sand & -0.929 & -0.818 & 1 & --- & --- & --- & --- & --- & --- \\
WRC & 0.389 & 0.261 & -0.359 & 1 & --- & --- & --- & --- & --- \\
MC & 0.17 & 0.078 & -0.127 & 0.309 & 1 & --- & --- & --- & --- \\
Desid & 0.156 & 0.016 & -0.112 & 0.157 & 0.227 & 1 & --- & --- & --- \\
OM & 0.122 & 0.064 & -0.093 & 0.275 & 0.365 & 0.499 & 1 & --- & --- \\
P. rich & -0.003 & -0.061 & 0.049 & 0.206 & 0.303 & 0.203 & 0.348 & 1 & --- \\
Arbo indiv & 0.031 & 0.004 & $-7 E-04$ & 0.14 & 0.312 & 0.227 & 0.405 & 0.6229 & 1 \\
\hline
\end{tabular}

confirming that local revegetation by planting seedlings of native species has aided the recovery of disabled tin mines in the Amazon rainforest.

\section{CONCLUSIONS}

Considering the self-organizing maps methodology applied to the results it was possible to identify different groups of degraded areas recovery disabled tin mines in the Amazon rainforest.

The indicators variables related to biological activity proved to be more correlated with the areas in which the fine particle size and water retention in the soil is greatest. In these areas the correlation between the number of tree species and individual wealth are larger.

The sandy areas even not correlate well with the variables associated with biological activity showed a correlation with the kind of wealth denoting that the planting of native species has aided the recovery of degraded areas in different deactivated mines. 


\section{REFERENCES}

[1] INSTITUTO BRASILEIRO DE MINERAÇÃO (IBRAM). Informações e Analises da Economia Mineral Brasileira (2011)d isponível em http://www.ibram.org.br/ sites/1300/1382/00001669.pdf

[2] LONGO, Regina Márcia; RIBEIRO, Admilson Írio and MELO, Wanderley José de.Uso da adubação verde na recuperação de solos degradados por mineração na floresta amazônica. Bragantia[online]. 2011, vol.70, n.1 [cited 2016-04-13], pp.139-146. Available from: <http://www.scielo.br/scielo.php?script=sci_arttext\&pid=S0006$87052011000100020 \& \operatorname{lng}=\mathrm{en} \& \mathrm{nrm}=\mathrm{iso}>$. ISSN 0006-8705. http://dx.doi.org/10.1590/S0006-87052011000100020

[3] EMBRAPA-EMPRESA BRASILEIRA DE PESQUISA AGROPECUÁRIA. Manual de métodos de análise de solo. 2. Edição . Rio de Janeiro, 2011. 225p

[4] VANCE Ed, BROOKES Pc, JENKINSON Ds. An extraction method for measuring soil microbial biomass C. Soil Biol Biochem. 1987;19:703-7.

http://dx.doi.org/10.1016/0038-0717(87)90052-6

[5] Melo WJ, Melo GMP, Araujo ASF, Melo VP. Avaliação da atividade enzimática em amostras de solo. In: Figueiredo MBV, Burity HA, Oliveira JP, Santos CERS, Stanford $\mathrm{NP}$, editores. Biotecnologia aplicada à agricultura: Textos de apoio e protocolos experimentais. Brasília/Recife: Embrapa Informação Tecnológica/ Instituto Agronômico de Pernambuco; 2010. p.153-87.

[6] Eder C. SANTOS, Eduardo Dutra ARMAS, David CROWLEY, Marcio Rodrigues LAMBAIS, Artificial neural network modeling of microbial community structures in the Atlantic Forest of Brazil, Soil Biology and Biochemistry, Volume 69, February 2014, Pages 101-109, ISSN 0038-0717, http://dx.doi.org/10.1016/j.soilbio.2013.10.049. (http://www.sciencedirect.com/science/article/pii/S0038071713003933)

[7] GIRAUDEL, J. L.; LEK, S. A comparison of self-organizing map algorithm and some conventional statistical methods for ecological community ordination. Ecological Modeling. v. 146, p. 329-339, 2001 http://dx.doi.org/10.1016/S0304-3800(01)00324-6

[8] YADA, Marcela Midori et al. Atributos Químicos e Bioquímicos em Solos Degradados por Mineração de Estanho e em Fase de Recuperação em Ecossistema Amazônico. Rev. Bras. Ciênc. Solo [online]. 2015, vol.39, n.3 [cited 2016-04-15], pp.714-724. Available from: <http://www.scielo.br/scielo.php?script=sci_arttext\&pid=S0100$06832015000300714 \& \operatorname{lng}=\mathrm{en} \& \mathrm{nrm}=\mathrm{iso}>$. ISSN 1806-9657. http://dx.doi.org/10.1590/01000683rbcs20140499.

[9] RIBEIRO, A. I.; R. M. Longo ; MELO, W. J. ; MACIEL, A. J.S. ; Lourenço, R.W. ; FRACETO, L. F. . Recovery of degraded areas using topsoil in the Amazon rainforest. WIT Transactions on Ecology and the Environment (Online), v. 167, p. 220-225, 2011. 